Winter 2008

\title{
Discreetly Depicting "an outrage": Graphic Illustration and "Daisy Miller"'s Reputation
}

Adam Sonstegard

Cleveland State University, a.sonstegard@csuohio.edu

Follow this and additional works at: https://engagedscholarship.csuohio.edu/cleng_facpub

Part of the American Literature Commons, Illustration Commons, and the Literature in English, North America Commons

How does access to this work benefit you? Let us know!

\section{Publisher's Statement}

Copyright (C) 2008 The Johns Hopkins University Press. This article first appeared in The Henry James Review, Volume 29, Issue 1, Winter 2008, 65-79. doi:10.1353/hjr.2008.0002

\section{Original Published Citation}

Sonstegard, A. "Discreetly Depicting "an outrage": Graphic Illustration and "Daisy Miller"'s Reputation." The Henry James Review, vol. 29 no. 1, 2008, pp. 65-79. Project MUSE, doi:10.1353/hjr.2008.0002

This Article is brought to you for free and open access by the English Department at EngagedScholarship@CSU. It has been accepted for inclusion in English Faculty Publications by an authorized administrator of EngagedScholarship@CSU. For more information, please contact library.es@csuohio.edu. 


\section{PROJECT MUSE*}

Discreetly Depicting "an outrage": Graphic Illustration and "Daisy Miller"'s Reputation

Adam Sonstegard

The

Johns

Hopkins

University

Press

Published by Johns Hopkins University Press

DOI: https://doi.org/10.1353/hjr.2008.0002

$\Rightarrow$ For additional information about this article https://muse.jhu.edu/article/231819 


\title{
Discreetly Depicting "an outrage": Graphic Illustration and "Daisy Miller"'s Reputation
}

\author{
By Adam Sonstegard, Cleveland \\ State University
}

“Daisy Miller” was rejected by a Philadelphia magazine because (a friend surmised) "it could only have passed with the Philadelphia critic for 'an outrage on American girlhood"” (NT 18: v). It was serialized, nonetheless, by one magazine in London, pirated by another in Boston, and published as a book on both sides of the Atlantic, as well as included within James's short-story collections. The novella divided the world (William Dean Howells claimed) into "Daisy Millerites and antiDaisy Millerites" and was adapted for the stage but never produced. In its most recent form, "Daisy Miller” appeared as Peter Bogdanovich's 1974 motion picture, in which Bogdanovich's then-girlfriend, Cybill Shepherd, embodied the pouting ingénue.

"Daisy Miller" also appeared in a hitherto neglected, visual, but pre-cinematic Jamesian form. The artist Harry Whitney McVickar and the editors at Harper and Brothers published the first illustrated "Daisy Miller" in 1892, fourteen years after readers formed their initial mental pictures of Daisy but some eighty years before Shepherd's movie portrayal. Daisy's first illustrator probably knew her as "an outrage on American girlhood" when he staged her visual-arts debut. The heroine and the novella already had a reputation, one might say, when Daisy Miller made her first appearance in visual illustrations.

One might well say that-if, indeed, she had fully appeared in the edition's illustrations. In truth, she does not. McVickar's images for his 1892 "Daisy Miller" virtually omit the heroine. They consign her to a stylish frontispiece that depicts her at a distance (and shows her from the back). They never once picture her face directly nor grant readers a view of her profile. McVickar seems in fact to present everything but Daisy, as fancy curlicues, elaborate calligraphy, renderings of sugar cubes, Alpine landscapes, and depictions of minor characters adorn the volume and manifest McVickar's attention to design and decorum but leave uninformed observers, who pick up the volume at random, without a clue as to the tale's conflict, Winterbourne's 
ambivalence, or Daisy's mischief. Harper and Brothers lend the tale its first-ever visual dimension but risk omitting its heroine. They publish the visual accompaniment to a text but exclude most of the action and characterization of the tale they mean it to accompany. As a Jamesian form, this illustrated edition obscures, even eclipses, Jamesian content.

However, if McVickar had chosen to illustrate Daisy directly, he could potentially have dispelled the novella's carefully maintained mysteries. If he had tried to capture her coquetry in graphic imagery, he would have confirmed her transgressions in visual, documentary modes. McVickar works instead to dissuade bachelors who followed Winterbourne to Europe in 1892 from replicating the hero's mistakes of courtship. McVickar contains in polite sketches, rather than amplifies in direct imagery, the young pair's indiscretions. He ensures that the next generation of aspiring flirts and would-be Winterbournes who casually flip through the volume will never "get the wrong idea." James's tale might encourage Winterbourne's voyeurism, but McVickar's illustrations make Daisy often heard (and heard about) but seldom seen. James's novella might follow a representative American man's youthful amours, but McVickar's edition omits all expatriates whom the publishers felt American tourists like Winterbourne should not be seeing while they were visiting Rome. The illustrations force readers to imagine the heroine's appearance and her admirer's gaze, without indulgently reproducing - and thereby tacitly approving — the young couple's indecorum with visual aids. For his part, James could not have anticipated the precise form that illustrations like McVickar's would take, but he could describe Daisy's gauche missteps in words, knowing that the conventional class of graphic illustrators assigned to the tale would in turn utilize the resources of the visual arts to save her reputation.

Based in New York, and seventeen years younger than James, Harry Whitney McVickar illustrated for Columbia University's Spectator and for Life, Harper's Weekly, and other top periodicals of the 1880s and ' 90 s. He provided illustrations for literary works by Charles Dudley Warner and Oliver Wendell Holmes, and he joined a select group of artists-including George DuMaurier, John LaFarge, Howard Pyle, C. S. Reinhart, and Joseph Pennell—in illustrating Henry James's writing. ${ }^{1}$ McVickar also produced his own books, including Our Amateur Circus (1891), Matrimonial Advice (1896), and Reptiles (1905), the first of which, Life Magazine claimed in a review, "reveals a new phase of his talent" ("Bookishness" 326). "Heretofore he had, for the most part, drawn beautiful women and well-dressed men in luxurious rooms," the reviewers explain and then write of his latest artistic departure, "these drawings are caricatures-grotesque attitudes, exaggerations, contortions, strange groupings, all telling their own story. He is a graceful satirist with the power of expressing himself in pictures, as well as the careful and skillful draughtsman who has long been recognized." Life's editors, describing their own artist and standing to profit from his success, recognize McVickar's facility with many graphic genres, ranging from serious to satirical to grotesque.

McVickar's The Evolution of Woman (1896) shows his facility in depicting the New Woman of the 1890s, Daisy's close kin. Women's “Evolution,” as Social Darwinism is applied here to gender politics, proceeds from skirts to bloomers to breeches. Sporting the last of these items, one McVickar creation coasts forward on a bicycle and makes dowdy men around her stand agape at her effrontery. Another, 
also clad in breeches, her arms akimbo, cocks her head flippantly to one side, seeming to ask of her breach of sartorial decorum, "what of it?" (see Fig. 1). Four rubes in top hats pantomime surprise and either stare at her or roll their eyes, looking silly in their censoriousness. McVickar distorts the male figures who react to women's nonconformity, but he renders the women without distortion or caricature. Only one small image of the bicycler, as she rides away from the viewer, exaggerates her proportions and posture. McVickar's women appear in realistic depictions as they bend the rules of social convention. It is the men who observe their behavior that McVickar bends out of shape.

McVickar certainly had the capacity, then, to render a satirical "Daisy Miller," but the artist and his editors aim instead for an edition that all but ignores James's heroine. "Daisy Miller" and An International Episode comprise a gift book of 296 pages, 134 of them devoted to "Daisy Miller." The story's text occupies the approximate width of a newspaper column and covers only a small portion of each page. McVickar exploits the resulting, wide margins for illustrations that seem free-ranging and expansive, next to the narrow columns of James's prose. "McVickar has also set out" (that is, placed within these margins) one reviewer explains, "silver bells and cockle-shells, and tubes of paint, and lumps of sugar, white castles and steeples and Mrs. James's favorite waiters and small boys seem to sprout up of themselves" (“Daisy Miller' Rediviva” 294). In this effect of playful spontaneity, a café's tables and chairs disappear behind the upper-most lines of type on one page, but Randolph Miller seems rudely to have taken his alpenstock and shoved aside the bottom-most lines of type on the same page (see Fig. 2). Text moves aside to make room for a waiter's elbow, alternates space on the page with oversized images of sugar cubes, and appears alongside an array of street signs advertising pensions and hotels. When the novella assumes a gently advisory tone-informing readers that Vevey's "remarkably blue lake" is one "that it behooves every tourist to visit" (GS 89), telling tourists "you receive an impression of these things at the excellent inn of the 'Trois Couronnes' and are transported in fancy to the Ocean House or to Congress Hall” (90)—it reads, as well as looks like, a traveler's guidebook. McVickar recreates the milieu of quaint pensions, complete with hotel marquees, which tourists, following their Baedekers, would see while abroad.

The volume's frontispiece, the only image that appears in colors other than black and white, combines yellow, brown, gray, green, and red to create a feminine figure who has turned her back to viewers (see Fig. 3). Only her hair and a small portion of her face emerge from her dress, a stiff, yellow gown with three rings of fur encircling her midriff and thereby concealing her body. The drawing shows more of the gown's folds and rumples than the supposed flirt's smiles and winks. Mists that arise around the figure recreate hazy mystery or suggest the Colosseum's "deadly miasma" fumes. A coat of arms features hearts and arrows, a knight's helmet sprouts a fleur de lis that spreads out in elegant patterns, and calligraphy seems intended to dignify the subject matter. These elements draw attention away from the heroine, who in any case does not return the viewer's gaze. If James's Daisy is "all exterior, or surface," as Sarah Wadsworth points out, "all ruffles and flounces and fashion and mannerisms" (115), McVickar correctly conceals her appearance, recreating her accessories instead. "Especially when she is nervous," writes Philip Page, "peripheral objects 


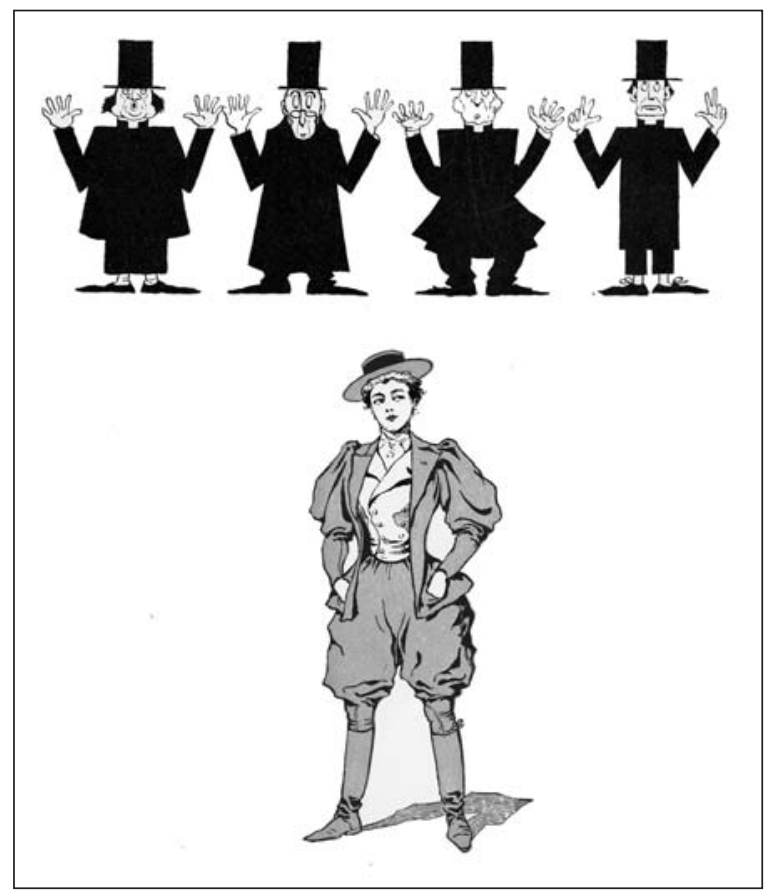

Figure 1. From Harry W. McVickar's The Evolution of Woman. New York: Harper, 1896, page 45.

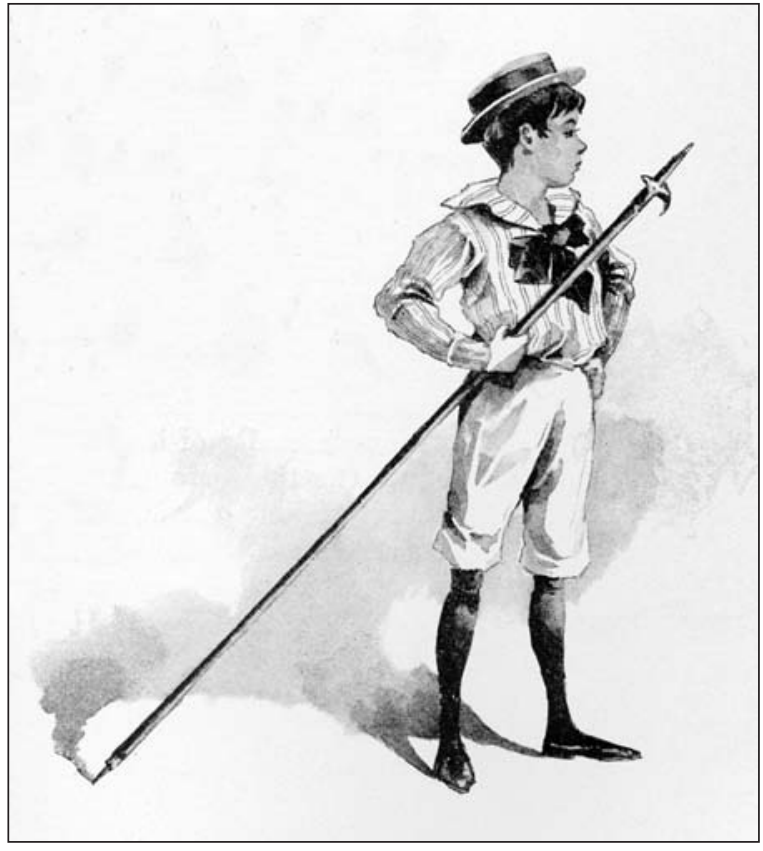

Figure 2. From Daisy Miller and An International Episode. Illustrated by Harry W. McVickar. New York: Harper, 1892, page 21. 


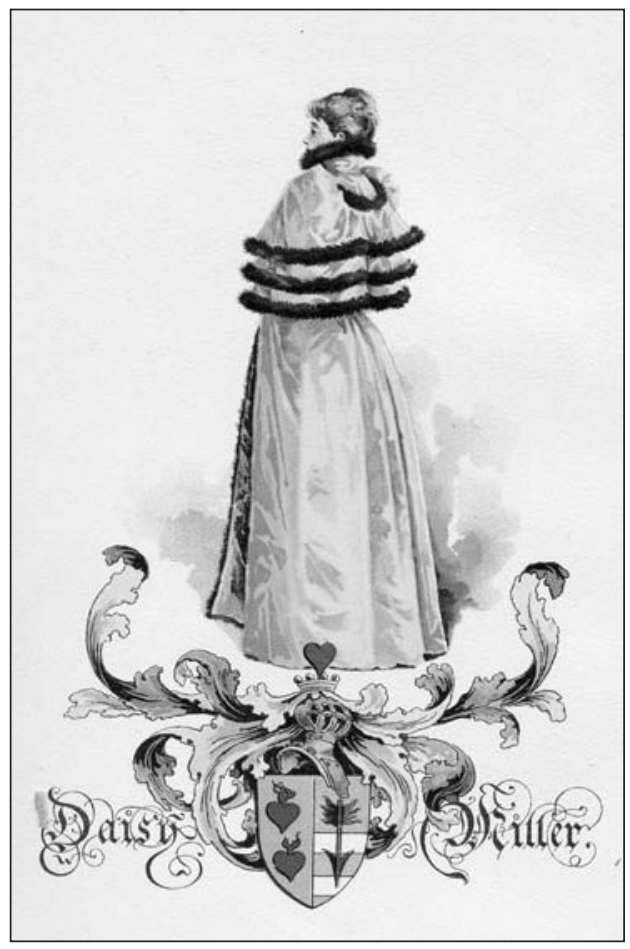

Figure 3. The frontispiece showing a mysterious Daisy at a distance. From Daisy Miller and An International Episode. Illustrated by Harry W. McVickar. New York: Harper, 1892, page ii.

receive her (and our, and presumably the other characters') attention, prohibiting the more constructive development of her relations with others" (593). In Swiss pensions within the story, as well as scattered across the page in this illustrated edition, intrusive, miscellaneous objects distract readers as well as characters, who might otherwise examine Daisy herself.

For a tale that recounts extensive social interactions, McVickar favors the solitary figure. In the only image to depict Winterbourne, the novella's young hero does not return the viewer's gaze, but peers over his coffee pot to glimpse a potted plant (see Fig. 4). His relaxed posture but stiffly creased pant legs distinguish him as an upperclass figure, yet make him seem prepared to model clothing in a fashion catalogue rather than figure within the story's action. Another solitary image revisits the novella's main character but does not depict her directly, picturing instead "Winterbourne's idea of Daisy Miller," as the table of contents titles the image (see Fig. 5). The image appears within a few pages of the moment Winterbourne's idealization of Daisy gives way to disappointment: "The news that Daisy Miller was surrounded by half a dozen wonderful mustaches checked Winterbourne's impulse to go straightaway to see her" (GS 116). Winterbourne, James writes, "had, perhaps, not definitely flattered himself that he had made an ineffaceable impression upon her heart, but he was annoyed at hearing of a state of affairs so little in harmony with an image that had lately flit- 


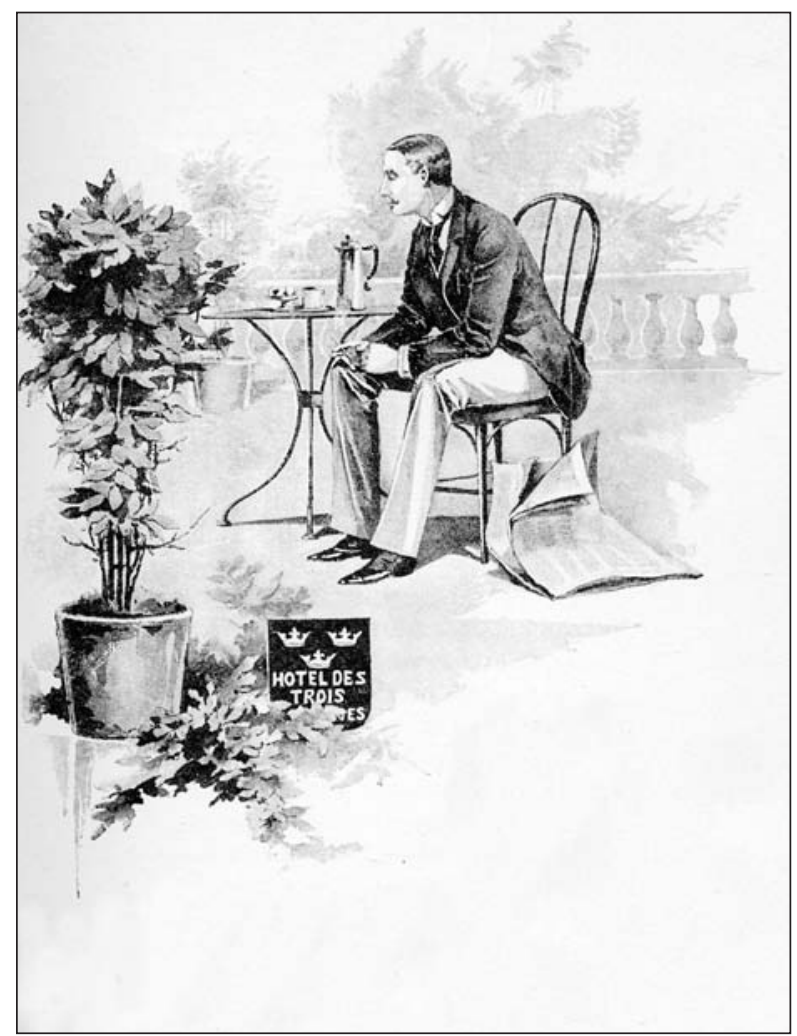

Figure 4. McVickar's image of Winterbourne. From Daisy Miller and An International Episode. Illustrated by Harry W. McVickar. New York: Harper, 1892, page 9.

ted in and out of his own meditations; the image of a very pretty girl looking out of an old Roman window and asking herself urgently when Mr. Winterbourne would arrive." Though the drawing obscures her exact location, the young woman gazes wistfully over a ledge or windowsill, her glance corresponding with Winterbourne's imagination and not with the actual facts of Daisy's busy social calendar. The artist colludes with the hero in lifting the heroine to an idealized realm where she is a more conventional fairy-tale figure, more solitary in her thoughts, and more exclusively preoccupied with Winterbourne than she ever is in the novella.

As he depicts other characters in the story line, and neglects others, McVickar continues his idiosyncratic patterns. Giovanelli, clownish in a polished top hat, wears a monocle and moustache, has a nosegay and a white-tipped wand, and wears a baggy overcoat and patterned trousers (see Fig. 6). His roguish mien dispels the mystery of whether Daisy has found a worthy companion in the man or stooped to entertain someone beneath her social station. If readers are to judge by McVickar's image, this exaggerated, clownish Italian seems scarcely worthy of the heroine's company. In McVickar's iconography, the man's appearance telegraphs "scoundrel” and confirms Daisy as a fool for trusting Giovanelli, for not seeing in him what McVickar quickly 


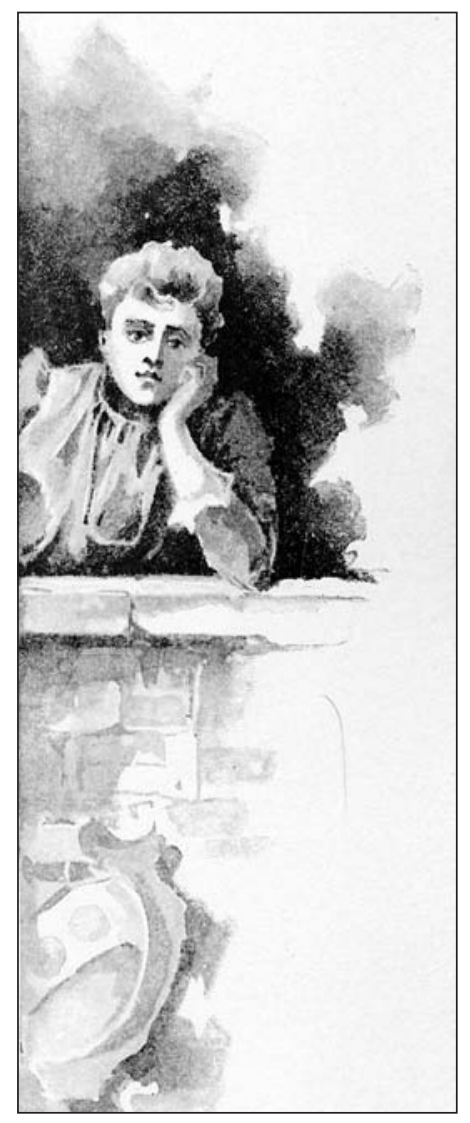

Figure 5. McVickar's image entitled "Winterbourne's idea of Daisy." From Daisy Miller and An International Episode. Illustrated by Harry W. McVickar. New York: Harper, 1892, page 71.

leads his viewers to see. McVickar also allows readers to see Mr. Miller, Daisy's father, who appears beside as well as beneath avalanches of papers and who seems aptly avuncular, if overworked. Mr. Miller, who never resides within the novella's European settings and is only referred to a total of seven times in the tale, figures nonetheless in McVickar's imagery. Mr. Miller's daughter, the eye of the novella's storm, merits only two obscure and distanced depictions. His wife, for all her discussion with Daisy and distress managing Randolph, never appears in McVickar's images at all.

McVickar's omissions begin to resonate with the exclusivity of the American tourists. Mrs. Walker in her carriage regally gestures toward someone situated outside of the picture frame, who is invisible to viewers (Fig. 7). Those viewers gaze at Mrs. Walker in her carriage, as Daisy would gaze at her while standing obstinately on the Roman street. Neither she nor Winterbourne nor Giovanelli appears, and the scene suggests nothing of the Roman passersby, who eye Daisy in her folly. James's tale pits an upper-class grand dame in her carriage against a neophyte of the nouveau riche, who prefers her own perambulation. But the only one who makes it into McVickar's 


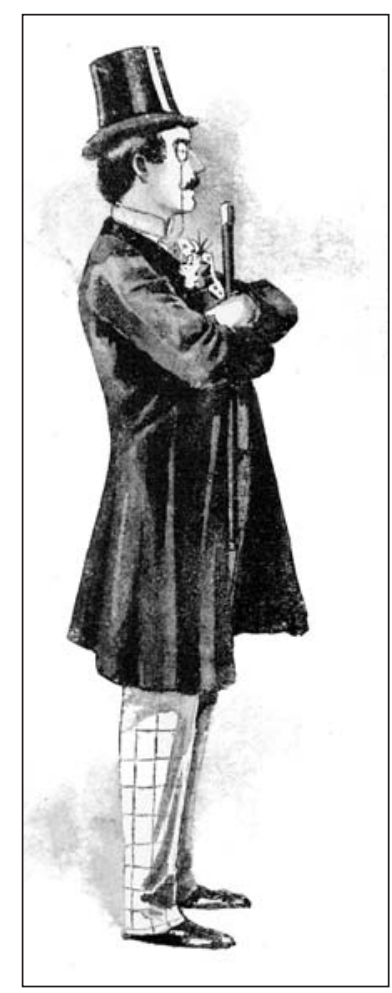

Figure 6. McVickar's conception of Daisy's Roman companion Giovanelli. From Daisy Miller and An International Episode. Illustrated by Harry W. McVickar. New York: Harper, 1892, page 79.

visual image is well-behaved and upper-crust. If James makes this scene in his comedy of manners a battle of wits-walker vs. Walker, as it were-McVickar's exclusive image makes it clear which contender wins.

Winterbourne's aunt, Mrs. Costello, stares critically into her eyeglasses in another illustration, but, left without any companions or background to lend her context, she examines nothing in particular. Her stiff Victorian gown, lace sleeves, clutched book, and raised glasses denote little that is forgiving or open-minded about her character, though the mists that surround her, rendered in uneven grays, recreate the vapors around Daisy in the frontispiece. Wadsworth points out that "the character of the charming American ingénue was rather too familiar to contemporary readers" of the 1880s, and "her cousin, the American Girl Abroad, or International American Girl, was simply a variation upon a theme," who was also "already in danger of becoming shelf-worn and hackneyed before James breathed new life into a genre whose moment had already passed" (108). If ingénues had become passé, surely dowagers were overly familiar, too, but McVickar leaves Mrs. Walker and Mrs. Costello intact, even stately on the page. His illustrations follow taste and innovation but also favor conservative, established figures. They erase overt signs of class struggle, removing all traces of the aspiring parvenu. 


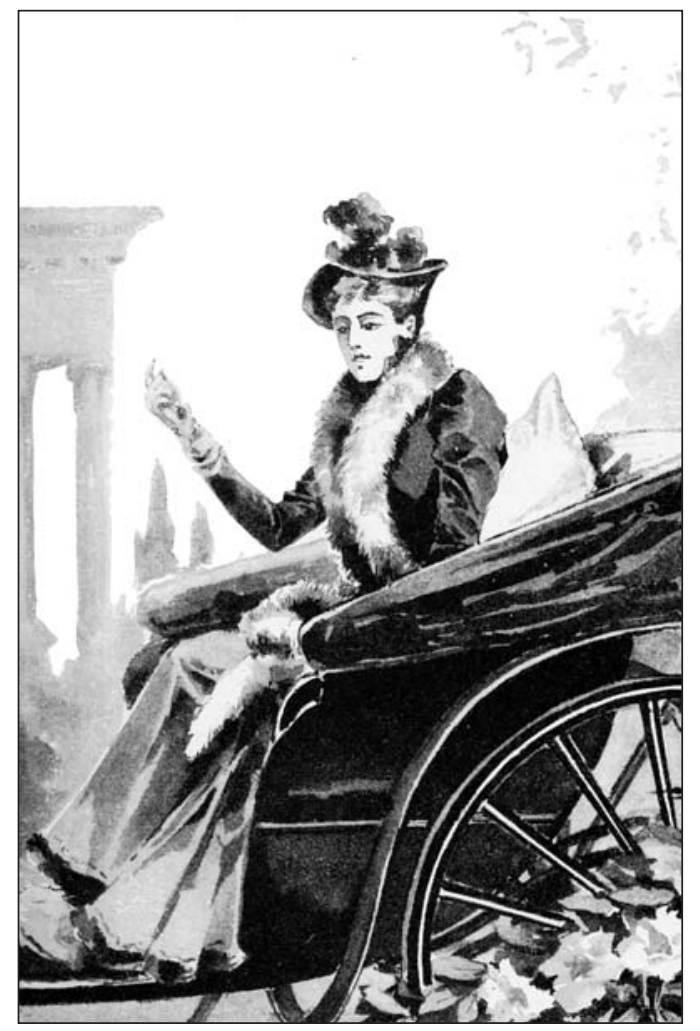

Figure 7. The image of Mrs. Walker in her carriage. From Daisy Miller and An International Episode. Illustrated by Harry W. McVickar. New York: Harper, 1892, page 93.

Three striking images of Daisy's death overshadow the scant depictions of her in life. The closest McVickar will come to depicting Daisy's unchaperoned entry into the Roman Colosseum is an architectural rendering of the ruins from a distance, in which shadow play in the structure's arches obscures readers' view of what happens within (see Fig. 8). An image that is at once bat, wraith, and skeleton hovers beneath the Colosseum, symbolizing the Roman Fever's noxious fumes. The picture more functions as an ominous warning to keep out than an evocation of a place the heroine recklessly ventured within. In the remaining images, an altar boy creeps beneath a candelabra of smoking tallow candles, and a wrought-iron marker stands over Daisy's lush, vernal grave. The pictures omit any parting images of Winterbourne. Daisy haunts, more than she is ever allowed to inhabit, her first illustrated edition.

Prevailing aesthetic tastes register John Ruskin's influence, as they partly explain the volume's chaste omissions. ${ }^{2}$ In "Cestus of Aglalia” (1866), Ruskin had articulated an ideal relationship between prose texts and visual illustrations, proposing that overdone visual elements could compete with the verbal art, detract from the story, and adversely affect readers. "It is not well to make the imagination indolent," Ruskin warned, "or to take its work out of its hands by supplying continual pictures 


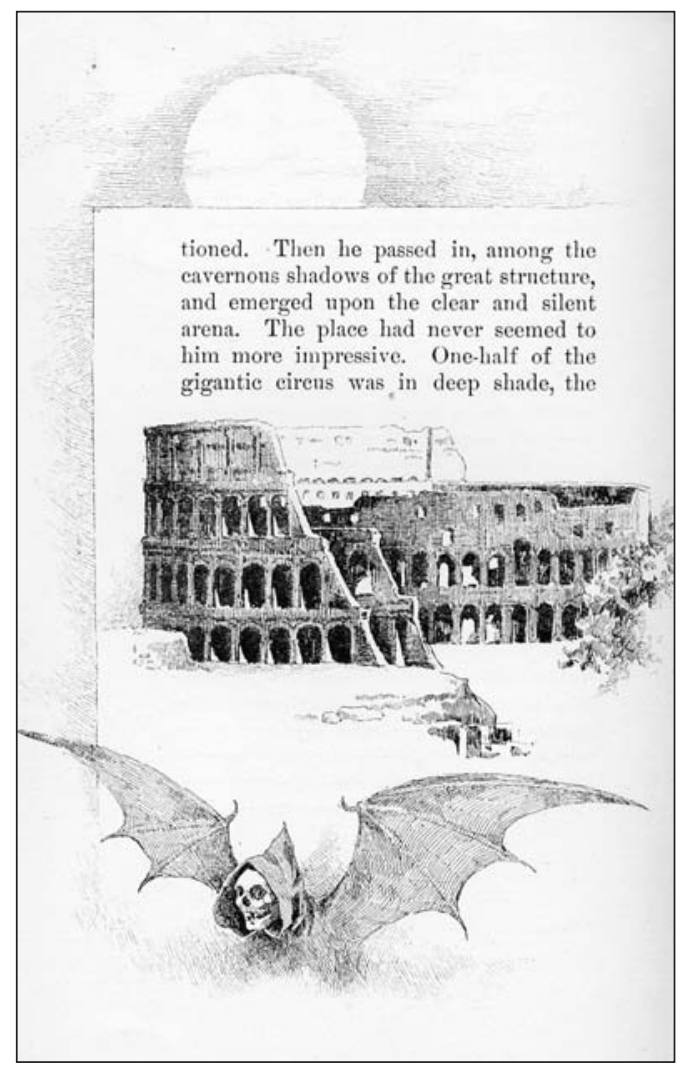

Figure 8. The closest McVickar will come to depicting Daisy's venture within the Roman Colosseum. From Daisy Miller and An International Episode. Illustrated by Harry W. McVickar. New York: Harper, 1892, page 122.

of what might be sufficiently conceived without pictures" (139). "The multiplication of these lovely but imperfect drawings," Ruskin wrote of one volume he found too abundantly illustrated, "is to increase the feverish thirst for excitement, and to weaken the power of attention by endless diversion and division" (140). Ruskin's fear of visual art's potential for side-show distractions at times becomes perversely acute. "A book of English verses," which Ruskin does not name, shows "large, skilful, appallingly laborious" illustrations, "dotted into textures like the dust on a lily leaf,- - smoothed through gradations like clouds,- - graved to surfaces like mother of pearl" (102). Overwrought workmanship not only diminishes appeal but endangers susceptible feminine readers:

[B]y this toil there is set forth for the delight of English women, a series of the basest dreams that ungoverned feminine imagination can coin in sickliest indolence,-ball-room amours, combats of curled knights, pilgrimages of disguised girl-pages, romantic pieties, charities in costume,- - a mass of disguised sensualism and feverish vanity-impotent, pestilent, prurient, 
scented with venomous elixir, and rouged with a deadly dust of outward good; and all this done, as such things can only be done, in a boundless ignorance of natural veracity: the faces falsely drawn-the lights falsely cast - the forms effaced and distorted, and all common human wit and sense extinguished in the vicious scum of lying sensation. (102)

Ruskin has an over-the-top reaction to overwrought imagery and fears feverishly stimulated feminine fancies. James, in Peter Rawlings's words, "distances himself from moral, homiletic approaches to art and life in Italy," “attacks Ruskin's moral high ground," and searches instead for "a site for encountering ethical dubieties and transgressive desires" (178). But if the novelist sought liberating, subversive visions, the aesthetician still warned that romantic, imaginative illustrations would wrongly influence viewers' moral perceptions. If a volume were conceived to be in poor taste or overly laden with inappropriate or suggestive imagery, more conservative, Ruskinian observers feared, women would wish to emulate characters such as Daisy rather than receive the artist's politely sketched suggestions of the errors of the heroine's ways.

A few contemporary reviewers, in fact, thought Harper and Brothers had erred with “Daisy Miller." Harper's had claimed in its advertising columns that "Daisy Miller has been drawn by McVickar 'in all her admirable prettiness, her fashionableness, her independence, her grace." A reviewer in Bedford's Monthly, J. Percival Pollard, truculently begged to differ: "The artist has done none of these things; he only gives one effort at portraiture, and that merely results in looking like a fashion-plate" (501). McVickar, Pollard concludes, does not dissuade ladies from acting like Daisy but risks encouraging them to dress like her instead. Conceding that "we are not among those who believe that Daisy Miller is one of the minor books of Mr. Henry James deserving of illustrations," the Literary World's reviewers add that "the holiday form which it has received from the publishers has too much of the quality of Daisy herself to commend itself to a fastidious taste" ("Holiday"). They describe the holiday edition of the novella and remark of McVickar's images, "There is a certain lack of delicacy and distinction in them, which is in very good keeping with the heroine's style, but which has the effect of noxiously exaggerating the bad points of Daisy Miller's character. We would trust her reputation with confidence in the hands of those who have read her in a plain volume rather than in an edition with illustrations of this kind." Because they amplify, rather than conceal Daisy's ill-bred antics, Literary World's reviewers decide, "The success of the volume is doubtful. Mr. McVickar, by the way, has so little confidence in himself as to refrain from giving a full-face or even a good profile of Miss Miller." The reviewers wish to have their criticism of McVickar both ways, faulting him for showing too much of Daisy's actions and too little of her profile. One wonders what McVickar could possibly have done to please them. He had nearly screened Daisy Miller out of "Daisy Miller," supplanting her with stiff dowagers, ominous wraiths, and scatterings of sugar cubes, but even with this restraint, some found his edition tastelessly conceived. They judged McVickar's chaste pen to have been insufficiently discreet in rendering Daisy's indiscretions.

Reading James's narrative within McVickar's illustrated edition certainly emphasizes the story's already conflicted attitude toward the act of looking. Winterbourne and his fellow observers are engaged in obsessive modes of seeing Daisy, but for readers, 
such modes are disrupted; they cannot observe her, but cannot help observing other, overzealous observers. This tactic culminates when a friend tells Winterbourne he has seen Velazquez's portrait of Pope Innocent X and then casually remarks, "And in the same cabinet, by-the-way, I had the pleasure of contemplating a picture of a different kind-that pretty American girl whom you pointed out to me last week" (135). The reader notes the ironic play on the word "innocent," understands the pretty flirt is a "picture," without being certain just what she exemplifies, but is never given an actual picture of Daisy. McVickar's edition only manifests a tendency that is already latent in James's narrative: to make everyone but readers all too privy to Daisy's spectacular appearances. These readers must witness instead how the rumor mills of the American colony in Rome churn out gossip each time someone glimpses Daisy. Mrs. Costello, Mrs. Walker, and the other Americans transform a few odd sightings of this heroine's indiscretions into the general, scandalous buzz that ruins her reputation. Such situations anticipate McVickar's illustrations from The Evolution of Woman (see Fig. 1): one can almost picture Daisy, her head angled flippantly to one side, and the cartoonish tourists, who seem just as silly as the rubes in the drawing, pantomiming exaggerated, wide-eyed shock and censoriously whispering their disapproval in hunched, conspiratorial huddles. Daisy should know better than to flout local custom in brazen, uninhibited ways. Her countrymen should also know better than to gossip about it so incessantly.

The novella's guidebook aspects also take on an added significance, as Harper and Brothers and McVickar insure that readers will take the expatriates' side and ostracize Daisy and not risk empathizing with her or even going so far as to replicate her behavior instead. If the novella itself guides expatriates through Swiss and Italian destinations, the illustrated edition extends these guidelines to include how to behave properly and how to overlook those who are crass enough to stray from proper decorum. Winterbourne might see a delicate grace within Daisy's alleged commonness, but Mrs. Walker knows her type by the book: "Mrs. Walker," it seems, "was one of those American ladies who, while residing abroad, make a point, in their own phrase, of studying European society; and she had on this occasion collected several specimens of her diversely-born fellow-mortals to serve, as it were, as textbooks" (129). For the "diversely-born" and for Winterbourne, Mrs. Walker has her Baedeker, in which Daisy does not appear. Winterbourne learns from his countrywoman's “textbooks” to exclude Daisy from his social set; readers learn from McVickar's book not to picture ladies of Daisy's ilk.

The language of the novella and the discretion of McVickar's designs in fact guide readers to make the correct decisions in their own exclusive social sets. Crucially, neither the author nor the artist trusts the reader to make the right social decisions intuitively. “'Does Mr. Winterbourne think,' [Daisy] added slowly, smiling, throwing back her head, and glancing at him from head to foot, 'that, to save my reputation, I ought to get into the carriage?'” (GS 126). The genteel hero, the model for later generations of readers like him, feels her glance upon him and finds it "so strange to hear her speak that way of her 'reputation.' But he himself, in fact, must speak in accordance with gallantry." But the narrator does not suppose readers automatically recognize this quality among Winterbourne's options but instead becomes tutelary, even peripatetic: "The finest gallantry here, was simply to tell her the truth; and the 
truth, for Winterbourne-as the few indications I have been able to give have made him known to the reader-was that Daisy Miller should take Mrs. Walker's advice." The narrator not only worries that he has not been explicit about Winterbourne's character, but also that readers might not know, any better than Winterbourne, how to conduct themselves in such situations: "He looked at her exquisite prettiness, and then he said, very gently, 'I think you should get into the carriage." Not taking any chances, this narrator guides readers through his decisions, ensuring, while not presupposing, that later generations of readers recognize gallantry when they see it. Later, when Daisy has the audacity to attend Mrs. Walker's party and when the host publicly shuns the uninvited guest, the narration takes Mrs. Walker's side, not remarking that she had been a cold, ungracious host, not saying she herself had erred but that she had "conscientiously repaired the weakness" (132), and also not automatically trusting readers to interpret the situation rightly. Mrs. Walker may be icy, but she is socially correct to ostracize Daisy. McVickar might be unimaginative, but he is aesthetically astute to turn away from her as well. "As the Millers move within their social orbit, the expatriates, led by the formidable Mrs. Walker," Peggy McCormack explains, "pull up the drawbridge against vulgar countrymen in order to define themselves as the better sort of Americans" (52). The tutelary narration and exclusive illustrations gently compel readers to side with this "better sort," not with subversives they might otherwise observe.

Winterbourne finally absorbs these lessons on whom to see and not to see when his nocturnal excursion to the Colosseum finally curbs his tendencies toward voyeurism. But McVickar has directed readers to look elsewhere all along, as if waiting for Winterbourne to realize that the time he has spent looking at Daisy is time misspent. The artist, in effect, makes parasols proliferate to obscure Daisy from view, forces readers to look away from her sooner than Winterbourne does, and, indeed, never lets viewers come under her spell, even as Winterbourne clearly comes under it. The expatriate upper-crust in the novella and the exclusive visual illustrator shun Daisy, as they implicitly teach readers that they may hear ladies of Daisy's ilk and certainly hear about them in polite drawing-room chatter but must never encourage such vulgar Americans by regarding them directly. Winterbourne makes that mistake, but the novella and its illustrations ensure subsequent suitors will neither follow their example, nor-heaven forbid-succeed in making a match.

James, in fact, knew he enjoyed greater license in describing his heroes and heroines in their gauche indiscretions than visual artists would enjoy in "graphically" depicting them. James kept visual illustrations out of his collections of short stories. He sometimes spoke harshly of editors' efforts to decorate his work when it appeared in illustrated periodicals. He argued that "anything that relieves responsible prose of the duty of being, while placed before us, good enough, interesting enough, and, if the question be of picture, pictorial enough, above all in itself, does it the worst of services (NT 13: ix-x). He allowed only Alvin Langdon Coburn's richly suggestive but indirect and atmospheric photographs within his New York editions. He wrote "Daisy Miller" in the knowledge, then, that his verbal suggestiveness would playfully tantalize readers and that the accompanying visual art would in turn enshroud his characters' excesses. Even if his verbal tale were to be "an outrage on American girlhood," he could still write it, knowing visual artists would work to redeem the girls' reputations. 
Recent critics of Bogdanovich's 1974 Daisy Miller praise the cinematographer's subordinating of the moviegoer's gaze to Winterbourne's point of view: "[Bogdanovich's] shots outside the hotel suggest that he (and we) wonder momentarily if [Daisy] is innocent" (McCormack 50); "As onlookers, we acknowledge our complicity in Winterbourne's watching and judging of the heroine" (Cross 131); and, in sum, "Where James draws a veil over proceedings, Bogdanovich has the courage and tact to do so too" (139). Cinematography looks at the heroine the same way the hero does; it looks away when doing so is in keeping with the spirit of the tale. And yet one wonders if a modern adaptation of "Daisy Miller" would be truer to the original if Cybill Shepherd never actually appeared, if occasional flounces, abandoned parasols, and shadows flitting across hotel parlor-room walls were all that visually represented the heroine. One wonders if viewers could be coached to act as if they had already learned Winterbourne's lessons about when not to look at fellow Americans abroad, rather than replicating his mistakes in staring indulgently at inept expatriates. McVickar's Jamesian form shows the original story is more about learning not to stare as Winterbourne stares, not to display as Daisy displays, than it is about encouraging viewers to see (and be seen) as James's hero and heroine do. Cinema encourages their antics and romanticizes their relationship, but this visual form, originating much closer in time to James's tale, contains and discourages them instead. Though a film showing flounces and shadows but never showing Daisy would sacrifice many cinematographic pleasures, it would more faithfully recreate McVickar's visual ethics, more accurately revisit the aesthetics of the original illustrated Jamesian form.

Decades before a visual artist brought Daisy to movie screens, after all, a graphic artist almost screened her out of the novel's first illustrated edition. People who view films today gaze more directly, more invasively, at women on screen than Winterbourne and men of his generation were ever empowered by technology to look at women like Daisy. In turn, people who wish to put themselves on public display have recourse to a vast array of cinematic, virtual, and interactive means that Daisy never had at her disposal. Modern electronic and cinematic media amplify and publicly broadcast what graphic and illustrative media, the original visual dimensions of many of James's fictions, politely suggest and chastely veil. In the transformation from black-and-white sketches on the published page in 1892 to direct depictions in larger-than-life cinematic imagery in 1974 (and beyond), heroines' transgressions in flirting too playfully, heroes' voyeurism in staring too directly, and viewers' implicit ethics of looking chastely away from couples' too-indecorous indiscretions threaten to be lost in the translation.

NOTES

${ }^{1}$ For critical studies of these and other artists' illustrations of James's tales, see Graham; Johanningsmeier ("Dalliance," "Real"); and Sonstegard.

${ }^{2} \mathrm{My}$ chief concern here is Ruskin's influence on McVickar. For Ruskin's influence on James, see Swafford; Rawlings; and Nichols and Hadley.

WORKS BY HENRY JAMES

Daisy Miller and An International Episode. Illustrated by Harry W. McVickar. New York: Harper, 1892.

GS-The Great Short Novels of Henry James. Ed. and intro. Philip Rahv. New York: Carroll, 1996.

NT-The Novels and Tales of Henry James. 26 vols. New York: Scribner's, 1907-17. 


\section{OTHER WORKS CITED}

"Bookishness." Life 3 Dec. 1891: 326.

Cross, David. "Framing the 'Sketch': Bogdanovich's Daisy Miller." Henry James on Stage and Screen. Ed. John R. Bradley. New York: Palgrave, 2000. 127-42.

“'Daisy Miller' Rediviva.” The Critic 26 Nov. 1892: 294.

Graham, Wendy. "Pictures for Texts." Henry James Review 24 (2003): 1-26.

"Holiday Books." Literary World 3 Dec. 1892: 443.

Johanningsmeier, Charles. "Henry James's Dalliance with the Newspaper World." Henry James Review 19 (1998): 36-52.

. "How Real American Readers Originally Experienced James's 'The Real Thing.'” Henry James Review 27 (2006): 75-99.

McCormack, Peggy. "Reexamining Bogdonavich's Daisy Miller." Henry James Goes to the Movies. Ed. Susan Griffin. Lexington: UP of Kentucky, 2002. 34-59.

McVickar, Harry Whitney. The Evolution of Woman. New York: Harper, 1896.

Nichols, Tom, and Tessa Hadley. "James, Ruskin, and Tintoretto." Henry James Review 23 (2002): 294-303.

Page, Philip. "Daisy Miller's Parasol.” Studies in Short Fiction 27 (1990): 591-601.

Pollard, J. Percival. "Glimpses." Belford's Monthly Feb. 1893: 501.

Ruskin, John. The Works of John Ruskin. Ed. E. T. Cook and Alexander Wedderburn. Vol. 19. London: George Allen, 1906.

Sonstegard, Adam. "'Singularly like a bad illustration': The Appearance of James's 'The Real Thing' in the Pot-Boiler Press." Texas Studies in Literature and Language 45 (2003): 173-200.

Rawlings, Peter. "Grotesque Encounters in the Travel Writing of Henry James." Yearbook of English Studies 34 (2004): 171-85.

Swafford, Kevin. "Italian Counterpoint: Henry James and John Ruskin in Florence." Victorian Newsletter 105 (Spring 2004): 1-6.

Wadsworth, Sarah A. "Innocence Abroad: Henry James and the Re-Invention of the American Woman Abroad." Henry James Review 22 (2001): 107-27. 